JA: Jurnal Al-Wasath 2 No.1: 19-32

Journal homepage: https://journal.unusia.ac.id/index.php/alwasath/index

ISSN 2721-6160 (Online)

\title{
Perlindungan Hukum Data Pribadi Sebagai Hak Privasi
}

\section{Sekaring Ayumeida Kusnadi}

Universitas Wijaya Putra

Andy Usmina Wijaya

Universitas Wijaya Putra

\begin{abstract}
Abstrak
Setiap orang pasti memiliki data pribadi. Data pribadi merupakan sesuatu yang melekat pada setiap orang. Data pribadi merupakan sesuatu yang bersifat sensitif. Data pribadi adalah sesuatu yang harus dilindungi karna sejatinya merupakan hak privasi setiap orang. Hak privasi adalah hak konstitusional warga negara yang telah diatur dalam Undang - Undang Dasar Negara republik Indonesia Tahun 1945. Hak konstitusional adalah kewajiban dari suatu negara terhadap warga negaranya. Tujuan dan fokus penelitian ini adalah menemukan hakekat dari perlindungan hukum data pribadi sebagai hak privasi dan bentuk perlindungan hukum data pribadi sebagai hak privasi di Indonesia. Metode penelitian yang digunakan dalam penelitian ini adalah yuridis normatif, melalui conseptual approach. Hasil dari penelitian ini adalah hakekat dari perlindungan hukum data pribadi sebagai hak privasi adalah hak konstitusional warga negara. Indonesia belum memiliki peraturan perundang - undangan yang menjadi dasar hukum perlindungan terhadap data pribadi. Maka dari itu, dalam perlindungan hukum data pribadi, Indonesia mengalami kekosongan norma sehingga tidak dapat secara maksimal melindungi data pribadi warga negara.
\end{abstract}

\section{Keywords:}

Perlindungan Hukum, Data Pribadi, Hak Privasi

\section{Corresponding Author:}

Sekaring Ayumeida Kusnadi

Universitas Wijaya Putra

Email: sekaring@uwp.ac.id

\section{Andy Usmina Wijaya}

Universitas Wijaya Putra

Email: andyusmina@uwp.ac.id

(C) The Author(s) 2021

DOI: 10.47776/alwasath.v2i1.127
Submitted: 25 Februari 2021

Accepted: 21 April 2021

Online: 21 April 2021

\section{Classification \\ Conceptual Article}

\footnotetext{
CC BY: This license allows reusers to distribute, remix, adapt, and build upon the material in any medium or format, so long as attribution is given to the creator. The license allows for commercial use.

\section{(c) (1)}




\section{PENDAHULUAN}

Setiap warga negara memiliki hak konstitusional, yaitu hak yang dijamin oleh UndangUndang. Dengan adanya hak konstitusional tersebut, maka negara memiliki kewajiban konstitusional, yaitu melindungi seluruh warga negara. Kewajiban konstitusional negara ini telah tertuang dalam Pembukaan Alinea Ke - 4 Undang-Undang Dasar Negara Republik Indonesia Tahun 1945 (UUDRI 1945) yang menyatakan bahwa negara wajib melindungi segenal bangsa Indonesia dalam meningkatkan kesejahteraan umum, mecerdaskan kehidupan bangsa, dan melaksanakan ketertiban dunia berdasar kemerdekaan, perdamaian dunia serta keadilan sosial.

Hak konstitusional yang diatur dalam UUDRI 1945 mencakup 40 hak warga negara. Salah satunya adalah hak atas perlindungan diri pribadi. Hak tersebut diatur pada Pasal 28 G Ayat (1) dengan garis besar bahwa warga negara berhak atas perlindungan diri pribadi, keluarga,kehormatan, martabat dan harta benda yang di bawah kekuasaannya. Pada pasal tersebut, mengasumsikan hak pribadi adalah hak milik. Tetapi, dengan berkembangnya teknologi informasi dan komunikasi harusnya hak pribadi tidak hanya diartikan sebagai hak milik. Hak pribadi seharusnya juga sebagai hak privasi. Hak privasi bersifat lebih sensitif yang dapat mewakili hak pribadi tersebut. Hak pribadi merupakan hal yang sensitif yang berkaitan dengan data pribadi atau identitas seseorang. Identitas tersebut mulai dari Kartu Tanda Penduduk (KTP), Surat Ijin Mengemudi (SIM), Paspor, Kartu Keluarga (KK), Nomor Pokok Wajib Pajak (NPWP), Nomor Rekening, Sidik jari, Ciri khas seseorang dan sebagainya.

Memberikan perlindungan terhadap hak atas privasi, berarti memberikan perlindungan pula terhadap hak atas kebebasan berbicara. Artinya, hak atas privasi menjamin perlindungan dari ancaman ketakutan untuk berbuat atau tidak berbuat sesuatu yang merupakan hak asasi. ${ }^{1}$

Indonesia saat ini telah memasuki Revolusi Industri 4.0. Segala hal dapat dikendalikan dari segala tempat melalui jaringan internet dan perangkat gawai yang saling terhubung. Implikasi dari era ini sangat besar ketika teknologi berbasis digital dipakai oleh masyarakat dalam kehidupan sehari-hari, misalnya untuk meningkatkan produktivitas kerja, membangun hubungan sosio-ekonomi, serta membantu memudahkan dalam berbagai hal. ${ }^{2}$ Perkembangan teknologi informasi komunikasi berbasis komputer telah berkembang sangat pesat di masyarakat. Masyarakat kemudian dimudahkan dengan perkembangan teknologi tersebut. ${ }^{3}$

Indonesia saat ini memiliki banyak peraturan mengenai perlindungan data pribadi, tetapi tersebar di beberapa Undang-Undang. Indonesia belum memiliki peraturan perundang-undangan khusus yang mengatur perlindungan hukum data pribadi yang dapat menjadi solusi diberbagai macam kasus yang berkaitan dengan penyalahgunaan data pribadi. Saat ini Indonesia telah memiliki Rancangan Undang -Undang Perlindungan Data Pribadi (RUU PDT). RUU PDT terseburt juga perlu dikaji lebih dalam karena pasti masih memiliki kekurangan dalam pengaturannya. Setidaknya Indonesia bisa membandingkannya dengan peraturan perlindungan data pribadi yang telah dimiliki negara lain, yaitu Hongkong, Malaysia, Singapura, Korea Selatan. Beberapa negara tersebut telah memiliki peraturan khusus yang menjamin perlindungan hukum data pribadi. Tetapi, dalam penelitian ini akan mengkaji perbandingan peraturan perlindungan data pribadi Malaysia dengan RUU PDT yang telah dimiliki Indonesia saat ini. Perbandingan tersebut dilakukan karena atmosfer kehidupan Malaysia tidak jauh beda dengan Indonesia. Meskipun atmosfer kehidupan di Indonesia dan Malaysia tidak jauh beda, tetapi dalam sistem hukum antara Indonesia dan Malaysia memiliki perbedaan. Sistem hukum di Indonesia menerapkan sistem hukum civil law system yaitu Hukum tertulis (kodifikasi). Ada pemisahan secara tegas dan jelas antara hukum publik dengan hukum privat. Sedangkan, sistem hukum di

\footnotetext{
${ }^{1}$ Cynthia,H , 2018, "Registrasi Data Pribadi Melalui Kartu Prabayar Dalam Perspektif Hak Asasi Manusia", Jurnal HAM, Vol.9 No.2, Hal 191 - 204

${ }^{2}$ Syaifudin.A, 2020, "Perlindungan Hukum Terhadap Para Pihak Di Dalam Layanan Financial Technology Berbasis Peer to Peer (P2P) Lending (Studi Kasus di PT. Pasar Dana Pinjaman Jakarta)", Dinamika, Vol.26 No.4, Hal.408421

${ }^{3}$ Aswandi, R, Putri R, Muhammad S, 2020, "Perlindungan Data dan Informasi Pribadi Melalui Indonesia Data Protection System (IDPS), Legislatif, Vol. 3 No.2, Hal.167-190
} 
Malaysia menerapkan common law system, yaitu didominasi oleh hukum tidak tertulis atau hukum kebiasaan melalui putusan hakim. Tidak ada pemisahan yang tegas dan jelas antara hukum publik dan privat. Dengan adanya perbedaan sistem hukum tersebut, dapat diterapkan asas universalitas yaitu demi kepentingan internasional dengan dilandasi pemikiran bahwa setiap Negara di dunia wajib turut melaksanakan tata hukum sedunia.

Berdasarkan latar belakang penelitian di atas, penelitian ini akan mempelajari permasalahan pokok sebagai berikut : 1) Apakah hakekat dari hak privasi terhadap data pribadi? 2) Bagaimana bentuk perlindungan hukum terhadap data pribadi sebagai hak privasi di Indonesia?

\section{METODOLOGI PENELITIAN}

Metode penelitian ini menggunakan metode penelitian yuridis normatif (legal research) menemukan kebenaran koherensi, adakah aturan hukum sesuai dengan norma hukum dan adakah norma yang berupa perintah atau larangan itu sesuai dengan prinsip hukum, serta apakah tindakan seseorang sesuai dengan norma hukum (bukan hanya sesuai aturan hukum) atau prinsip hukum. Penelitian ini menggunakan pendekatan yaitu pendekatan konsep (conseptual approach). Pendekatan konseptual (conceptual approach) dilakukan manakala peneliti tidak beranjak dari aturan hukum yang ada. Hal itu dilakukan karena memang belum atau tidak ada aturan hukum untuk masalah yang dihadapi.

\section{HASIL DAN PEMBAHASAN}

\section{Hakekat Dari Hak Privasi Terhadap Data Pribadi}

Konsep privasi untuk pertama kalinya dikembangkan oleh Warren dan Brandheis yang menulis sebuah artikel di dalam jurnal ilmiah Sekolah Hukum Universitas Harvard yang berjudul "The Right to Privacy" atau hak untuk tidak diganggu. Dalam jurnal tersebut menurut Warren dan Brandheis dengan adanya perkembangan dan kemajuan teknologi maka timbul suatu kesadaran masyarakat bahwa telah lahir suatu kesadaran bahwa ada hak seseorang untuk menikmati hidup. ${ }^{4}$

Menurut Warren dan Brandeis menyatakan bahwa :

"Privacy is the rught to enjoy life and the right to be left alone and this development of the law was inevitable and demanded of legal recognition". ${ }^{5}$ Privasi adalah suatu hak setiap orang untuk menikmati hidup dan menuntut privasinya untuk dilindungi. ${ }^{6}$

Alasan hak privasi harus dilindungi adalah, Pertama, dalam membina hubungan dengan orang lain, seseorang harus menutupi sebagian kehidupan pribadinya sehingga dia dapat mempertahankan posisinya pada tingkat tertentu. Kedua, seseorang di dalam kehidupannya memerlukan waktu untuk dapat menyendiri sehingga privasi sangat diperlukan oleh seseorang, Ketiga, privasi adalah hak yang berdiri sendiri dan tidak bergantung kepada hak lain akan tetapi hak ini akan hilang apabila orang tersebut mempublikasikan hal-hal yang bersifat pribadi kepada umum. Keempat, privasi juga termasuk hak seseorang untuk melakukan hubungan domestik termasuk bagaimana seseorang membina perkawinan, membina keluarganya dan orang lain tidak boleh mengetahui hubungan pribadi tersebut sehingga kemudian Warren menyebutnya sebagai the right against the word. Kelima, alasan lain mengapa privasi patut mendapat perlindungan hukum karena kerugian yang diderita sulit untuk dinilai. Kerugiannya dirasakan jauh lebih besar dibandingkan dengan kerugian fisik, karena telah menganggu kehidupan pribadinya, sehingga bila ada kerugian yang diderita maka pihak korban wajib mendapatkan kompensasi. ${ }^{7}$

\footnotetext{
${ }^{4}$ Latumahina, RE, 2014, "Aspek Hukum Perlindungan Data Pribadi Di Dunia Maya", Jurnal GEMA AKTUALITA, Vol.3, No. 2, Hal. 14-25

${ }^{5}$ Rosadi, SD, 2015, Cyber Law Aspek Data Privasi Menurut Hukum Internasional, Regional dan Nasional, Refika Aditama, Jakarta,Hal. 23

${ }^{6}$ Rosadi, SD, 2015, Cyber Law Aspek Data Privasi Menurut Hukum Internasional, Regional dan Nasional, Refika Aditama, Jakarta, Hal. 23

${ }^{7}$ Dewi, S, 2017, Prinsip - Prinsip Perlindungan Data Pribadi Nasabah Kartu Kredit Menurut Ketentuan Nasional dan Implementasinya", Sosiohumaniora, Vol.19 No. 3, Hal. 206 - 212
} 
Alan Westin memberikan pengertian privasi sebagai "Privacy is the claim of individuals, groups, or institutions to determine for themselves when, how, and to what extent information about them is communicated to others (privasi adalah klaim individu, kelompok, atau institusi untuk menentukan sendiri kapan, bagaimana,dan sejauh mana informasi tentang mereka dikomunikasikan kepada orang lain). ${ }^{8}$

Hak privasi merupakan salah satu hak yang melekat pada diri setiap orang. Hak privasi merupakan martabat setiap orang yang harus dilindungi. Data pribadi adalah data yang berkenaan dengan ciri seseorang, nama, umur, jenis kelamin, pendidikan, pekerjaan, alamat, dan kedudukan dalam keluarga. ${ }^{9}$ Data pribadi merupakan hal yang sensitif dimiliki setiap orang. Data pribadi menjadi hak privasi seseorang yang wajib dilindungi dari berbagai aspek kehidupan.

Beberapa instrumen internasional seperti OECD Guidelines maupun Data Protection Convention dari Dewan Eropa data pribadi diartikan semua informasi yang berhubungan dengan orang-perorangan yang teridentifikasi dan dapat diindetifikasi ("information relating to an identified or identifiable natural person"). ${ }^{10}$

Pengertian lain dari "data pribadi" adalah data yang berupa identitas, kode, simbol, huruf atau angka penanda personal seseorang yang bersifat pribadi dan rahasia. ${ }^{11}$

Memiliki sifat yang sensitif menjadikan data pribadi suatu hal yang menarik bagi orang lain karena banyak sekali kebutuhan kegiatan seseorang yang berkaitan dengan data pribadi seseorang. Data pribadi merupakan suatu aset atau komoditas bernilai ekonomi tinggi. ${ }^{12}$

Titik awal dari hukum di Indonesia pasti berasal dari Kosntitusi dan peraturan perundangundangan yang berlaku. UUD 1945 mengatur bahwa setiap orang berhak atas perlindungan diri pribadi, keluarga, kehormatan, martabat, dan harta benda yang di bawah kekuasaannya, serta berhak rasa aman dan perlindungan dari ancaman ketakutan. ${ }^{13}$ Dalam UUDNRI 1945 khususnya pada pasal 28 huruf G Ayat (1) menyatakan bahwa "Setiap orang berhak atas perlindungan diri pribadi, keluarga, kehormatan, martabat, dan harta benda yang di bawah kekuasaannya, serta berhak atas rasa aman dan perlindungan dari ancaman ketakutan untuk berbuat atau tidak berbuat sesuatu yang merupakan hak asasi”.

Konsep perlindungan data mengisyaratkan bahwa individu memiliki hak untuk menentukan apakah mereka akan membagi atau bertukar data pribadi mereka atau tidak. Selain itu, individu juga memiliki hak untuk menentukan syarat-syarat pelaksanaan pemindahan data pribadi tersebut. Lebih jauh, perlindungan privasi. Hak privasi telah berkembang sehingga dapat digunakan untuk merumuskan hak untuk melindungi data pribadi. ${ }^{14}$

Dengan dasar hukum tersebut, maka hak privasi terhadap data pribadi harus dilakukan dan perlindungan terhadap data pribadi sebagai hak privasi merupakan Hak Konstitusional warga negara Indonesia. Hak konstitusional adalah kewajiban bagi negara untuk memberikan perlindungan secara hukum untuk aspek kehidupan masyarakat Indonesia. Hak konstitusional harus didapatkan oleh setiap warga negara Indonesia. Hak konstitusional harus memiliki tujuan hukum yaitu kepastian hukum, keadilan hukum dan kemanfaatan hukum. Dengan dasar hukum

\footnotetext{
${ }^{8}$ Yuniarti, S, 2019, "Perlindungan Hukum Data Pribadi Di Indonesia", Jurnal Becoss, Vol. 1 No.1, Hal. 147-154

${ }^{9}$ Mahira, DF, Emilda Y Lisa NA, 2020, "Consumer Protection System (CPS): Siste, Perlindungan Data Pribadi Konsumen Melalui Collaboration Concept”, Legislatif, Vol.3 No.2, Hal.287-302

${ }^{10}$ Rosadi, SD, 2017, "Implikasi Penerapan program E-Health Dihubungkan Dengan Perlindungan Data Pribadi", Arena Hukum, Vol.9 No.3, Hal. 403-420

${ }^{11}$ Sautunnida, L, 2018,"Urgensi Undang-Undang Perlindungan Data Pribadi Di Indonesia;Studi perbandingan Hukum Inggris dan Malaysia”, Kanun Jurnal Ilmu Hukum, Vol. 20 No.2, Hal. 369-384

${ }^{12}$ Hanifan N, 2020, "Perlindungan Data Pribadi Sebagai Bagian Hak Asasi Manusia Atas Perlindungan Diri pribadi Suatu Tinjauan Komparatif Dengan Peraturan Perundang-undangan Di Negara Lain”, Selisik, Vol.6 No.1. Hal 26856816

${ }^{13}$ Anggraeni, SF, 2018, "Polemik Pengaturan Kepemilikan Data Pribadi : Urgensi Untuk Harmonisasi dan Reformasi Hukum Di Indonesia", Jurnal Hukum \& Pembangunan, Vol. 48 No. 4, 814 - 825

${ }^{14}$ Erna, P 2019, "Pentingnya Perlindungan Data Pribadi Dalam Transaksi Pinjaman Online (The Urgency of Personal Protection in Peer to Peer Lending)", Majalah Hukum Nasional, No.2, Hal 1-27
} 
tersebut juga beberapa peraturan perundang - undangan di Indonesia mengatur secara tersirat mengenai perlindungan data pribadi.

\section{Perlindungan Hukum Terhadap Data Pribadi Sebagai Hak Privasi Di Indonesia Perlindungan Hukum Data Pribadi di Malaysia}

Malaysia telah memiliki peraturan perundang - undangan untuk melindungi data pribadi yaitu The Personal Data Protection Act No. 709 of 2010 (PDPA Malaysia). Secara berkala dari tahun 1998, Menteri Malaysia sudah secara konsisten melakukan perencanaan pembentukan undang - undang berkaitan dengan perlindungan data pribadi. Kemudian pada tahun 2010 telah disahkan PDPA Malaysia yang ditindak lanjuti dengan pembentukan Departemen Perlindungan Data Pribadi yang dalam naungan Kementrian Informasi Komunikasi dan Kebudayaan.

Dalam PDPA Malaysia memiliki prinsip perlindungan hukum data pribadi yang terdapat dalam Seksi 5 sampai dengan Seksi 12 PDPA Malaysia, sebagai berikut :

1. Prinsip Umum Pengolahan Berdasarkan Persetujuan (Seksi 6) yang mengatur pengguna data tidak diperbolehkan mengolah data pribadi dengan pengecualian telah mendapat persetujuan dari pemilik data.

2. Keabsahan, Kebutuhan dan Tidak Berlebihan (Seksi 6 Ayat (3)) mengatur tentang batasan umum dalam pengolahan data pribadi, sebagai berikut :

(a) Pengolahan data pribadi dilakukan demi tujuan yang sah dan memiliki kaitan dengan aktivitas pengguna data.

(b) Pelaksanaan pengolahan data wajib berkaitan langsung dengan tujuan.

(c) Data pribadi yang diolah harus memenuhi kualifikasi yang baik untuk pencapaian tujuan dari pengolahan serta tidak berlebihan.

3. Prinsip Pengumpulan dan Pemberitahuan. Pengumpulan data pribadi harus sepengetahuan dan pesetujuan pemilik data serta pengguna data wajib melakukan pemberitahuan secara tertulis berkaitan dengan tujuan pengumpulan data pribadi.

4. Prinsip Penggunaan Dan Pengungkapan (Seksi 6 Ayat (3)). Data pribadi dapat digunakan dan diolah apabila dengan maksud dan tujuan yang sah, berkaitan dengan pengguna data dan tujuan pengumpulan data dengan pengolahan data harus saling berkaitan.

5. Data Pribadi Sensitif merupakan data pribadi berkaitan dengan kondisi fisik, mental, agama, kepercayaan, tuduhan melakukan pelanggaran, pilihan politik dan hal - hal lain yang ditentukan.

6. Prinsip Keamanan. Prinsip ini harus dimiliki setiap pengguna data sesuai dengan kebijakan yang ditentukan oleh Komisioner dalam perlindungan data pribadi.

7. Prinsip Retensi Data dan Hak Memblokir Pemrosesan. Apabila tujuan yang sah dari pengguna data sudah tercapai, maka pengguna data harus memastikan bahwa data pribadi tersebut telah dimusnahkan secara permanen karena pengguna data wajib taat pada retensi standar dari Komisioner Perlindungan Data Pribadi.

8. Prinsip Integritas Data. Pengguna data pribadi dapat memastikan bahwa data peribadi tersebut akurat, up to date, dan tidak menyesatkan dengan langkah yang wajar.

9. Prinsip Akses dan Koreksi. Pemilik data pribadi memmpunyai hak untuk memperbaruhi, memperbaiki apabila data pribadinya dianggap tidak akurat, menyesatkan dan tidak up to date.

Melalui Personal Data Protection Act 2010, Malaysia membentuk Komita Penasihat Perlindungan Data Pribadi yang bertugas menerima laporan jika terjadi penyalahgunaan dan pemindah tanganan data pribadi secara melawan hukum. ${ }^{15}$

\footnotetext{
${ }^{15}$ Rizal, MS, 2019, Perbandingan Perlindungan Data Pribadi Indonesia dan Malysia, Jurnal Cakrawala Hukum, DOI:
} https://doi.org/10.26905/idjch.v10i2.3349. 218-227. 
Aturan dari Personal Data Protection Act 2010, ini bertujuan untuk mengatur pengolahan data pribadi oleh pengguna data dalam konteks transaksi komersial, dengan maksud menjaga kepentingan subjek data itu. Hal ini dicapai dengan memastikan bahwa persetujuan dari subjek data diperoleh sebelum pengolahan data pribadi serta memberikan data dengan subjek hak untuk mengakses, benar dan juga kontrol pengolahan data pribadi mereka. ${ }^{16}$

Malaysia tidak mendefinisikan privasi dengan eksplisit kedalam kebebasan dasar. Pengadilan Federal Malaysia memiliki penafsiran berkaitan dengan kebebasan pribadi yang terdapat di Pasal 5 Ayat (1) Konstitusi Malaysia yang mencakup beberapa hak, salah satunya yaitu hak privasi. Dengan dasar tersebutlah perlindungan privasi berkembang. PDPA Malaysia juga mengatur mengenai sanksi denda maupun pidana penjara.

\section{Perlindungan Hukum Data Pribadi di Singapura}

Singapura telah memiliki pengaturan hukum perlindungan hukum terhadap data pribadi yaitu The Personal Data Protection Act No. 26 of 2012 Singapore (PDPA 2012). Dalam PDPA 2012 yang dimiliki Singapura, tertuang beberapa prinsip dalam perlindungan hukum data pribadi :

\section{Prinsip Consent}

Suatu organisasi, dapat memperoleh, menggunakan atau membuka data pribadi seseorang apabila mendapat kesepakatan dari subjek data.

\section{Prinsip Purpose}

Suatu organisasi dapat memperoleh atau mengumpulkan, menggunakan dan membuka data pribadi seseorang dalam keadaan apapun, dan apabila mereka menginformasikan kepada subjek data tujuan dari diminta atau dikumpulkannya, digunakan dan diumumkannya data pribadi seseorang kepada yang bersangkutan.

\section{Prinsip Reasonableness}

Suatu organisasi dapat mengumpulkan, menggunakan atau mengumumkan data pribadi seseorang apabila ia melakukannya dengan tujuan yang pantas dan beralasan. ${ }^{17}$

PDPA mengakui hak pribadi untuk melindungi data pribadi miliknya, termasuk hak untuk mengakses dan membetulkan, juga kebutuhan suatu organisasi untuk mengumpulkan, menggunakan data pribadi untuk maksud tertentu. ${ }^{18}$

Esensinya, organisasi wajib untuk memberitahu kepada seseorang untuk mengumpulkan data pribadi dan memperoleh persetujuan orang tersebut sebelum pengumpulan, penggunaan, dan pengungkapan data pribadi seseorang tersebut. Dalam hal seseorang bersedia untuk memberikan data pribadinya untuk maksud tertentu, orang tersebut dapat juga memperbolehkan organisasi untuk mengumpulkan, menggunakan, serta mengungkapkan data pribadinya. Peraturan mengakui konsep "deemed consent", atau persetujuan yang diberikan secara diam-diam untuk digunakan untuk maksud dan tujuan tertentu. ${ }^{19}$

PDPA 2012 yang dimiliki Singapura juga mengatur mengenai sanksi baik denda maupun pidana yaitu dengan denda sampai USD 790.000 dan/atau sanksi pidana penjara sampai dengan 3 (tiga) tahun.

\section{Perlindungan Hukum Data Pribadi di Hongkong}

Hongkong telah memiliki pengaturan hukum yang mengatur perlindungan hukum terhadap data pribadi yaitu Personal Data Privacy Ordinance of 1995 (PDPO) yang mengalami perubahan

\footnotetext{
16 Ibid

${ }^{17}$ Sugeng, 2020, Hukum Telematika, Jakarta, Prenadamedia Group, Hal. 66

${ }^{18}$ Op.Cit, Anggraeni, Hal. 821

${ }^{19}$ Ibid 
pada tahun 2012, perubahan tersebut dilakukan karna tidak seluruh prinsip didalam PDPO tahun 1995 terlaksana dengan baik.

Dalam PDPO 2012 menghasilkan beberapa prinsip perlindungan hukum terhadap data pribadi, sebagai berikut :

1. Batasan Pengumpulan Data Pribadi. Dalam pengumpulan data pribadi harus memiliki tujuan yang sah dan memiliki ikatan dengan pengumpul data serta pengumpulan data tidak diperkenankan melebihi dari tujuan pengumpulan itu sendiri.

2. Penggunaan dan Pengungkapan Data Pribadi. Pengungkapan data pribadi hanya boleh dilakukan sesuai dengan tujuan awal dan persetujuan dari pemilik data pribadi.

3. Kewajiban Kualitas Data dan Pemberian Saran kepada Pihak ketiga. Kewajiban untuk menjamin akurasi data serta menghapus atau tidak menggunakan data yang tidak akurat dalam seluruh proses.

4. Penghapusan dan Pemusnahan Data Pribadi. Data pribadi tidak boleh disimpan terlalu lama dan tidak lama dari waktu tercapainya tujuan.

5. Kewajiban Keamanan Data. Pengguna data pribadi wajib memberikan penjaminan terhadap keamanan data pribadi tersebut dari suatu tindakan yang tidak sengaja dan tanpah hak melakukan tindakan terhadap data pribadi tersebut.

6. Keterbukaan Mengenai Praktik - Praktik. Prinsip ini menjadi dasar Komisioner untuk menjadikan suatu kewajiban untuk organisasi dan badan hukum Hongkong dalam mempublikasi kebijakan Privasi kepada publik.

\section{Perlindungan Hukum Data Pribadi di Korea Selatan}

Korea Selatan menjadi salah satu negara yang memiliki aturan hukum yang baik dan terdepan. Korea Selatan pada tahun 2011 juga telah memiliki aturan dalam perlindungan terhadap data pribadi yaitu Personal Information Protection Act (PIPA). Dari total populasi penduduk Korea Selatan sekitar 50 juta penduduk, lebih dari 40 juta penduduk adalah pengguna internet. Dengan kata lain 80 persen dari total penduduk Korea Selatan adalah pengguna internet. ${ }^{20}$ Dengan fakta inilah Korea Selatan menyusun urgensi - urgensi hukum dalam hal perlindungan data privasi demi keamanan data pribadi penduduk Korea Selatan yang sebgaian besar adalah pengguna internet.

Konstitusi Korea memberikan perlindungan umu privasi, khususnya perlindungan privasi di tempat tinggal dan privasi dalam berkomunikasi. ${ }^{21}$

Prinsip perlindungan data pribadi di Korea Selatan termuat dalam Pasal 3 PIPA 2011. Pemroses data pribadi harus memenuhi beberapa prinsip, antara lain:

a) Memiliki tujuan yang jelas dan spesifik

b) Memproses data pribadi hanya untuk pencapaian tujuan pengumpulan data pribadi;

c) Memastikan data pribadi akurat dan lengkap serta mukhtakhir;

d) Memperhatikan keamanan data pribadi;

e) Mengumumkan kebijakan privasi dan menjamin hak akses;

f) Mengelola dengan cara yang tidak melanggar hak subjek data;

g) Berusaha mengelola data pribadi tanpa menyerahkan nama subjek data, apabila mungkin; dan

h) Berusaha meningkatkan kepercayaan subjek data dengan mentaati ketentuan hukum. ${ }^{22}$

\section{Perlindungan Hukum Data Pribadi di Indonesia}

Konsep perlindungan data pribadi menekankan bahwa setiap orang berhak menentukan nasibnya sendiri seperti apakah dirinya akan melakukan sharing data atau tidak dan apabila

\footnotetext{
${ }^{20}$ Rosadi, DS, Op.cit, Hal. 73

${ }^{21}$ Ibid, Hal 74

${ }^{22}$ Sugeng, Op.cit, Hal. 66
} 
sharing data dilakukan maka ia berhak juga menentukan syarat yang hendak dipenuhi dalam suatu komunitas masyarakat. ${ }^{23}$

Saat ini Indonesia belum memiliki peraturan perundang - undangan yang khusus untuk mengatur perlindungan terhadap data pribadi, tetapi Indonesia telah memiliki Rancangan Undang - Undang Perlindungan Data Pribadi yang sampai saat ini belum disahkan dan diundangkan. Indonesia saat ini memiliki beberapa peraturan perundang - undangan yang berkaitan dengan perlindungan data pribadi, sebagai berikut :

\section{Undang - Undang Nomor 10 Tahun 1998 tentang Perbankan (Selanjutnya disebut UU Perbankan)}

Dalam UU Perbankan tentu telah mengenal kata "rahasia bank". Dalam Pasal 1 Ayat (28) menyatakan bahwa "Rahasia bank adalah segala sesuatu yang berhubungan dengan nasabah penyimpanan dan simpanannya". Hal ini menjelaskan bahwa segala informasi apapun yang berkaitan dengan nasabah penyimpanan serta simpanannya di bank adalah suatu hal yang sensitif dan bersifat rahasia.

Dalam Pasal 40 Ayat (1) menyatakan bahwa "Bank Wajib merahasiakan keterangan mengenai Nasabah Penyimpan dan simpanannya, kecuali dalam hal sebagaimana dimaksud dalam Pasal 41, Pasal 41A, Pasal 42, Pasal 44, dan Pasal 44A".

Berdasarkan pasal tersebut, maka bank memiliki kewajiban untuk melindungi seluruh informasi atau data mengenai nasabah penyimpan dan simpanannya. Tetapi, terdapat pengecualian yaitu dalam hal kepentingan perpajakan atas permintaan Menteri keuangan, penyelesaian piutang bank yang diserahkan kepada Badan Urusan Piutang dan Lelang Negara, kepentingan peradilan pidana, dan nasabah penyimpan meninggal dunia kepada ahli waris yang sah.

\section{Undang - Undang Nomor 36 Tahun 1999 tentang Telekomunikasi (Selanjutnya disebut UU Telekomunikasi)}

Dalam UU Telekomunikasi terdapat pasal yang mengatur tentang perlindungan data pribadi secara umum, tidak secara eksplisit dan spesifik data pribadi. Dalam Pasal 42 Ayat (1) UU Telekomunikasi menyatakan bahwa "Penyelenggara jasa telekomunikasi wajib merahasiakan informasi yang dikirim dan atau diterima, oleh pelanggan jasa telekomunikasi melalui jaringan telekomunikasi dan atau jasa telekomunikasi yang diselenggarakannya". Dengan adanya pasal ini penyelenggara jasa wajib untuk menjamin keamanan atas segala informasi yang akan dikirim ataupun diterimanya melalui jaringan telekomunikasi atau jasa telekomunikasi.

Dalam UU Telekomunikasi dalam Pasal 42 Ayat (2) menyatakan tentang pengecualian perlindungan data pribadi yaitu "Untuk keperluan proses peradilan pidana, penyelenggara jasa telekomunikasi dapat merekam informasi yang dikirim dan atau diterima oleh penyelenggara jasa telekomunikasi serta dapat memberikan informasi yang diperlukan atas :

a. Permintaan tertulis Jaksa Agung dan atau Kepala Kepolisian Republik Indonesia untuk tindak pidana tertentu;

b.Permintaan penyidik untuk tindak pidana tertentu sesuai dengan Undang-undang yang berlaku".

UU Telekomunikasi juga mengatur mengenai sanksi pidana terhadap penyalahgunaan dari informasi ttersebut yaitu terdapat dalam Pasal 57 yang menyatakan bahwa "Penyelenggara jasa telekomunikasi yang melanggar ketentuan sebagaimana dimaksud dalam Pasal 42 ayat (1), dipidana dengan pidana penjara paling lama 2 (dua) tahun dan atau denda paling banyak Rp. 200.000.000,00 (dua ratus juta rupiah)".

\footnotetext{
${ }^{23}$ Fanny, P, 2019, "Perlindungan Privasi data Pribadi Perspektif Perbandingan Hukum”,Jatiswara, Vol.34 No. 3, Hal. $239-249$
} 


\section{Undang - Undang Nomor 8 Tahun 1999 tentang Perlindungan Konsumen (Selanjutnya disebut UU PK)}

Dalam UU PK hanya memiliki Pasal 2 yang secara global mengatur perlindungan konsumen yang menyatakan bahwa "Perlindungan konsumen berasaskan manfaat, keadilan, keseimbangan, keamanan dan keselamatan konsumen, serta kepastian hukum". Undang - undang ini tidak secara rinci dan spesifik mengatur perlindungan dari segi apa saja yang harus didapatkan oleh konsumen, padahal segala kegiatan yang mencakup konsumen pasti berkaitan dengan data pribadi konsumen pula. Tidak mungkin suatu transaksi antara pelaku usaha dan konsumen dapat dilakukan tanpa adanya pengumpulan atau pengolahan data pribadi konsumen. UU PK menjadi sangat lemah dalam hal perlindungan data pribadi konsumen karna tidak secara tegas menyatakan dan mengatur hal tersebut. UU PK lebih fokus pada hak dan kewajiban konsumen serta pelaku usaha secara umum yang menimbulkan nilai ekonomis. Dengan tidak adanya perlindungan data pribadi konsumen yang diatur dalam undang - undang ini, maka konsumen di Indonesia tidak memiliki dasar hukum yang kuat dalam mendapatkan perlindungan data pribadi miliknya.

\section{Undang - Undang Nomor 39 Tahun 1999 tentang Hak Asasi Manusia (UU HAM)}

UU HAM merupakan peraturan perundang - undangan yang mengatur hak - hak yang melekat dalam diri seseorang. Pada Pasal 14 Ayat (1) menyatakan bahwa "Setiap orang berhak untuk berkomunikasi dan memperoleh informasi yang diperlukan untuk mengembangkan pribadi dan lingkungan sosialnya". Dengan adanya pasal ini, menegaskan bahwa setiap orang memiliki hak untuk memperoleh suatu informasi yang menjadi kebutuhannya dalam kehidupan sehari hari dengan tujuan perkembangan diri pribadi dan lingkungan kehidupannya.

Dalam UU HAM juga mengatur mengenai perlindungan diri pribadi yaitu pada Pasal 29 Ayat (1) menyatakan bahwa "Setiap orang berhak atas perlindungan diri pribadi, keluarga, kehormatan, martabat, dan hak miliknya". Pasal ini seperti halnya dengan Pasal 28 Huruf G Ayat (1) UUDNRI 1945 yang juga mengatur tentang hak setiap orang atas perlindungan diri pribadi.

Dalam UU HAM juga terdapat pengecualian tentang perlindungan data pribadi yaitu dalam Pasal 32 yang menyatakan bahwa "Kemerdekaan dan rahasia dalam hubungan surat-menyurat termasuk hubungan komunikasi sarana elektronika tidak boleh diganggu, kecuali atas perintah hakim atau kekuasaan lain yang sah sesuai dengan ketentuan peraturan perundangan".

\section{Undang - Undang Nomor 14 Tahun 2008 tentang Keterbukaan Informasi Publik (Selanjutnya disebut UU KIP)}

Dalam UU KIP mendefinisikan informasi dalam Pasal 1 Angka (1) yang menyatakan bahwa "Informasi adalah keterangan, pernyataan, gagasan, dan tanda-tanda yang mengandung nilai, makna, dan pesan, baik data, fakta maupun penjelasannya yang dapat dilihat, didengar, dan dibaca yang disajikan dalam berbagai kemasan dan format sesuai dengan perkembangan teknologi informasi dan komunikasi secara elektronik ataupun nonelektronik". Dalam pasal tersebut definisi informasi dijelaskan secara rinci apa yang termasuk dalam kategori informasi. Informasi juga merupakan satu hal yang dikemas dalam format yang mengikuti perkembangan teknologi baik elektronik maupun non elektronik. Sedangkan definisi informasi publik dalam Pasal 1 Angka (2) UU KIP menyatakan bahwa "Informasi Publik adalah informasi yang dihasilkan, disimpan, dikelola, dikirim, dan/atau diterima oleh suatu badan publik yang berkaitan dengan penyelenggara dan penyelenggaraan negara dan/atau penyelenggara dan penyelenggaraan badan publik lainnya yang sesuai dengan Undang-Undang ini serta informasi lain yang berkaitan dengan kepentingan publik". Dalam pasal ini menjelaskan bahwa informasi publik merupakan "informasi” yang telah 
mendapatkan pengolahan atau pengumpulan oleh badan publik yang berkaitan dengan penyelenggara serta kepentingan publik atau masyarakat.

Dalam UU KIP juga menjelaskan beberapa jenis informasi publik yang dimaksudkan dalam Pasal 1 Angka (2). Dalam Pasal 6 Ayat (3) menyatakan bahwa : Informasi Publik yang tidak dapat diberikan oleh Badan Publik, sebagaimana dimaksud pada ayat (1) adalah:

a. Informasi yang dapat membahayakan negara;

b. Informasi yang berkaitan dengan kepentingan perlindungan usaha dari persaingan usaha tidak sehat;

c. Informasi yang berkaitan dengan hak-hak pribadi;

d. Informasi yang berkaitan dengan rahasia jabatan; dan/atau

e. Informasi Publik yang diminta belum dikuasai atau didokumentasikan".

Berdasarkan Pasal 6 Ayat (3) tersebut khususya pada huruf (c) secara tersirat bahwa hal tersebut merupakan upaya perlindungan hak - hak pribadi atas informasi. Informasi publik pasti berkaitan dengan diri seseorang/masyarakat/kelompok yang tercakup ke dalam kepentingan publik. Pasal tersebut menjadi salah satu dasar perlindungan data pribadi karena terdapat larangan terhadap informasi publik yang berkaitan dengan hak - hak pribadi tidak diperbolehkan untuk diberikan kepada publik.

Dalam UU KIP juga mengatur mengenai informasi - informasi publik apa sasja yang termasuk pengecualian yang tidak menjadi kewajiban badan publik untuk memberikan akses kepada setiap pemohon informasi publik, yaitu dalam Pasal 17 yang menjelaskan bahwa informasi publik yang apabila dibuka dan diberikan akan menghambat proses penagakan hukum; informasi publik yang apabila dibuka dan diberikan akan mengganggu kepentingan perlindungan hak atas kekayaan intelektual dan persaingan usaha tidak sehat; informasi publik yang dapat membahayakan pertahanan dan keamanan negara; informasi publik yang dapat mengungkapkan kekayaan alam Indonesia; informasi publik yang dapat merugikan ketahanan ekonomi; informasi publik yang dapat merugikan kepentingan hubungan luar negeri; informasi publik yang dapat mengungkapkan isi akta otentik yang pribadi dan wasiat seseorang; informasi publik yang dapat mengungkap rahasia pribadi. Berdasarkan pasal tersebut, bagi mereka yang membuka akses atau memberikan informasi publik tersebut kepada pihak yang tidak berwenang maka akan mendapatkan sanksi pidana sesuai dengan Pasal 54 yang menegaskan bahwa bagi setiap orang yang sengaja dan tanpa hak mengakses, memperoleh, memberikan informasi dalam Pasal 17 akan dipidana dengan pidana penjara paling lama 2 (dua) tahun dan pidana denda paling banyak Rp 10.000.000,00 (Sepuluh juta rupiah).

Pasal - pasal tersebut merupakan salah satu wujud dari upaya perlindunngan data pribadi yang tersirat dalam UU KIP.

\section{Undang - Undang Nomor 36 Tahun 2009 tentang Kesehatan (Selanjutnya disebut UU Kesehatan)}

Jika berbicara mengenai kesehatan, maka pasti banyak sekali pihak yang terkait dalam hal ini. Khsususnya di Indonesia sebagai negara hukum, maka sudah pasti dan wajib untuk setiap aspek kehidupan masyarakat memiliki dasar hukum yang pasti, adil dan manfaat. Dalam kesehatan pasti pula berkaitan dengan data pribadi setiap pihak yang terkait, baik dari penyelenggara layanan kesehatan, dokter, pasien, maupun tenaga medis.

Dalam kegiatan pelayanan kesehatan sudah pasti seorang dokter ataupun pasien dan tenaga medis wajib memberikan informasi atau data pribadinya guna dapat melaksanakan pelayanan kesehatan dengan baik. Kesehatan juga menjadi aspek kehidupan masyarakat yang sangat penting. Jika pelayanan kesehatan tidak dilaksnakan dengan baik, maka tidak bisa dikatakan baik pula pemerintahannya. 
Dalam UU Kesehatan khususnya dalam Pasal 57 Ayat (1) menyatakan bahwa "Setiap orang berhak atas rahasia kondisi kesehatan pribadinya yang telah dikemukakan kepada penyelenggara pelayanan kesehatan". Dalam pasal ini menegaskan bahwa, perlindungan data pribadi seseorang bersifat sangat sensitif dalam dunia kesehatan, baik data tersebut adalah nama, nomor pasien, nomor kamar pasien, rekam medik, riwayat penyakit ataupun hasil pemeriksaan kesehatan. Perlindungan data pribadi ini tentunya harus dilakukan oleh siapapun yang terkait didalam pelayanan kesehatan tersebut. Menyebutkan nama dokter saja kita harus benar- benar memastikan akibat apa jika memberikan data tersebut kepada seseorang, karna data pribadi adalah hal yang sensitif yang terkadang bagi seseorang data tersebut boleh diinformasikan kepada siapapun tetapi ada pula yang memandang data tersebut tidak boleh diberikan kepada seseorang yang tidak berkaitan dengan data tersebut.

Dalam UU Kesehatan juga mengatur pengecualian terkait rahasia pribadi dalam kesehatan, yaitu dalam Pasal 57 Ayat (2) yang menyatakan bahwa Ketentuan mengenai hak atas rahasia kondisi kesehatan pribadi sebagaimana dimaksud pada ayat (1) tidak berlaku dalam hal:

a. perintah undang-undang;

b. perintah pengadilan;

c. izin yang bersangkutan;

d. kepentingan masyarakat; atau

e. kepentingan orang tersebut.

\section{Undang - Undang Nomor 24 Tahun 2013 tentang Perubahan Atas Undang - Undang Nomor 23 Tahun 2006 tentang Administrasi Kependudukan (Selanjutnya disebut UU AK)}

UU AK memiliki definisi mengenai data pribadi yaitu terdapat pada Pasal 1 Angka 22 yang menyatakan bahwa "Data Pribadi adalah data perseorangan tertentu yang disimpan, dirawat, dan dijaga kebenaran serta dilindungi kerahasiaannya". Berdasarkan pasal tersebut, maka upaya untuk melakukan perlindungan terhadap data pribadi. UU AK juga menegaskan bahwa perlindungan data pribadi harus dijamin oleh negara yang dinyatakan dalam Pasal 79 Ayat (1), Pasal 85 Ayat (1) dan Pasal 85 Ayat (3). Dua pasal tersebut dengan tegas menyatakan bahwa perlindungan atas data kependudukan adalah kewajiban negara baik kebenaran dan penyimpanan dokumen tersebut.

Pasal 84 Ayat (1) menyebutkan data prbadi apa saja data pribadi yang menjadi kewajiban negara melindunginya yaitu : keterangan cacat fisik dan/atau mental; sidik jari; iris mata; tanda tangan dan elemen data lain berkaitan dengan aib seseorang. Dalam pasal tersebut lebih menitikberatkan perlindungan data pribadi kepada sesuatu yang dapat mengakibatkan terbukanya aib seseorang.

\section{Undang - Undang Nomor 19 Tahun 2016 tentang Perubahan Atas Undang - Undang Nomor 11 Tahun 2008 tentang Informasi dan Transaksi Elektronik (Selanjutnya disebut UU ITE)}

"Kecuali ditentukan lain oleh peraturan perundangundangan, penggunaan setiap informasi melalui media elektronik yang menyangkut data pribadi seseorang harus dilakukan atas persetujuan Orang yang bersangkutan" (Pasal 26 Ayat (1). Dalam pasal tersebut sudah menegaskan bahwa perlindungan data pribadi harus dilakukan. Setiap tindakan terhadap data pribadi seseorang wajib dilakukan atas persetujuan dari pemilik data. 
Pasal 26 Ayat (1) adalah satu - satunya pasal yang dengan jelas menegaskan perlindungan data pribadi ahrus dilakukan. UU ITE juga mengatur tentang perbuatan yang dilarang berkaitan dengan bidang informasi elektronik yang tidak secara spesifik dalam data pribadi yaitu dalam Pasal 27 sampai dengan Pasal 37. Secara garis besar pasal - pasal tersebut melarang adanya perbuatan tanpa hak dan dengan sengaja menyalahgunakan informasi elektronik yang dapat merugikan orang lain terutama pemilik informasi.

\section{KESIMPULAN DAN SARAN}

Hakekat dari hak privasi terhadap data pribadi adalah hak kosntitusional warga negara Indonesia yang telah diatur dalam UUDNRI Tahun 1945 khususnya pada pasal 28 huruf G ayat (1). Bentuk perlindungan hukum terhadap data pribadis ebagai privasi di Indonesia saat ini menerapkan beberapa pasal yang tersirat mengatur mengenai data pribadi. Indonesia belum memiliki peraturan perundang - undangan khusus yang menjadi dasar hukum pelrindungan data pribadi sehingga saat ini Indonesia memiliki kekosongan norma.

\section{REFERENSI}

\section{Peraturan Perundang - undangan}

Undang -Undang Dasar Negara Republik Indonesia Tahun 1945

Undang - Undang Nomor 10 Tahun 1998 tentang Perbankan

Undang - Undang Nomor 36 Tahun 1999 tentang Telekomunikasi

Undang - Undang Nomor 8 Tahun 1999 tentang Perlindungan Konsumen

Undang - Undang Nomor 39 Tahun 1999 tentang Hak Asasi Manusia

Undang - Undang Nomor 14 Tahun 2008 tentang Keterbukaan Informasi Publik

Undang - Undang Nomor 36 Tahun 2009 tentang Kesehatan

Undang - Undang Nomor 24 Tahun 2013 tentang Perubahan Atas Undang - Undang Nomor 23

Tahun 2006 tentang Administrasi Kependudukan

Undang - Undang Nomor 19 Tahun 2016 tentang Perubahan Atas Undang - Undang Nomor 11

Tahun 2008 tentang Informasi dan Transaksi Elektronik

Naskah Akademik Undang - Undang Perlindungan Data Pribadi

Anggraeni, SF, 2018, "Polemik Pengaturan Kepemilikan Data Pribadi : Urgensi Untuk Harmonisasi dan Reformasi Hukum Di Indonesia", Jurnal Hukum \& Pembangunan, Vol. 48 No. 4, $814-825$

Aswandi, R, Putri R, Muhammad S, 2020, "Perlindungan Data dan Informasi Pribadi Melalui Indonesia Data Protection System (IDPS), Legislatif, Vol. 3 No.2, Hal.167-190

Bambang Pratama, 2018,"Data Pribadi (Elektronik) Dalam Perspektif Uu-Ite”, https://businesslaw.binus.ac.id/2018/12/07/data-pribadi-elektronik-dalam-perspektif-uu-ite/.

Cynthia,H , 2018, "Registrasi Data Pribadi Melalui Kartu Prabayar Dalam Perspektif Hak Asasi Manusia", Jurnal HAM, Vol.9 No.2, Hal 191 - 204

Dewi, S, 2017, Prinsip - Prinsip Perlindungan Data Pribadi Nasabah Kartu Kredit Menurut Ketentuan Nasional dan Implementasinya", Sosiohumaniora, Vol.19 No. 3, Hal. $206-212$

Erna, P 2019, "Pentingnya Perlindungan Data Pribadi Dalam Transaksi Pinjaman Online (The Urgency of Personal Protection in Peer to Peer Lending)", Majalah Hukum Nasional, No.2, Hal 1-27

Fanny, P, 2019, "Perlindungan Privasi data Pribadi Perspektif Perbandingan Hukum",Jatiswara, Vol.34 No. 3, Hal. 239-249 
Hanifan N, 2020, "Perlindungan Data Pribadi Sebagai Bagian Hak Asasi Manusia Atas Perlindungan Diri pribadi Suatu Tinjauan Komparatif Dengan Peraturan Perundangundangan Di Negara Lain", Selisik, Vol.6 No.1. Hal 2685-6816

http://digilib.uinsby.ac.id/19036/5/Bab\%202.pdf. Hal. 21, Diakses pada tanggal 09 Februari 2020

Latumahina, RE, 2014, "Aspek Hukum Perlindungan Data Pribadi Di Dunia Maya", Jurnal GEMA AKTUALITA, Vol.3, No. 2, Hal. 14-25

Mahira, DF, Emilda Y Lisa NA, 2020, "Consumer Protection System (CPS): Siste, Perlindungan Data Pribadi Konsumen Melalui Collaboration Concept”, Legislatif, Vol.3 No.2, Hal.287-302

Rizal, MS, 2019, Perbandingan Perlindungan Data Pribadi Indonesia dan Malysia, Jurnal Cakrawala Hukum, DOI: https://doi.org/10.26905/idjch.v10i2.3349. 218-227.

Rosadi, SD, 2015, Cyber Law Aspek Data Privasi Menurut Hukum Internasional, Regional dan Nasional, Refika Aditama : Jakarta.

Rosadi, SD, 2015, Cyber Law Aspek Data Privasi Menurut Hukum Internasional, Regional dan Nasional, Refika Aditama, Jakarta,Hal. 23

Rosadi, SD, 2017, "Implikasi Penerapan program E-Health Dihubungkan Dengan Perlindungan Data Pribadi”, Arena Hukum, Vol.9 No.3, Hal. 403-420

Sautunnida, L, 2018,'Urgensi Undang-Undang Perlindungan Data Pribadi Di Indonesia;Studi perbandingan Hukum Inggris dan Malaysia", Kanun Jurnal Ilmu Hukum, Vol. 20 No.2, Hal. 369-384

Sugeng, 2020, Hukum Telematika, Prenadamedia Group : Jakarta.

Syaifudin.A, 2020, "Perlindungan Hukum Terhadap Para Pihak Di Dalam Layanan Financial Technology Berbasis Peer to Peer (P2P) Lending (Studi Kasus di PT. Pasar Dana Pinjaman Jakarta)", Dinamika, Vol.26 No.4, Hal.408-421

Yuniarti, S, 2019, "Perlindungan Hukum Data Pribadi Di Indonesia", Jurnal Becoss, Vol. 1 No.1, Hal. 147-154

Zakky, 2018,"Pengertian Keadilan Menurut Para Ahli dan Secara Umum Beserta Macam Macam Keadilan", https:/www.zonareferensi.com/pengertian-keadilan/. 


\section{Competing interests}

No conflict interest.

\section{Funding.}

None.

\section{Acknowledgements.}

Thank you to all those who have supported and helped this research.

\section{About the Authors}

The authors is a lecture at Universitas Wijaya Putra 